\title{
Correction: Pseudomonas sfluorescens SBW25 produces furanomycin, a non-proteinogenic amino acid with selective antimicrobial properties
}

\author{
Kristin Trippe ${ }^{1}$, Kerry McPhail ${ }^{2}$, Donald Armstrong ${ }^{3}$, Mark Azevedo ${ }^{1}$ and Gary Banowetz ${ }^{1 *}$
}

It has come to our attention that the additional files (Additional files 1, 2, 3, 4, 5 and 6) in this article [1] are incorrect. The correct files can be accessed via this correction article. We apologize for any inconvenience.

\section{Additional files}

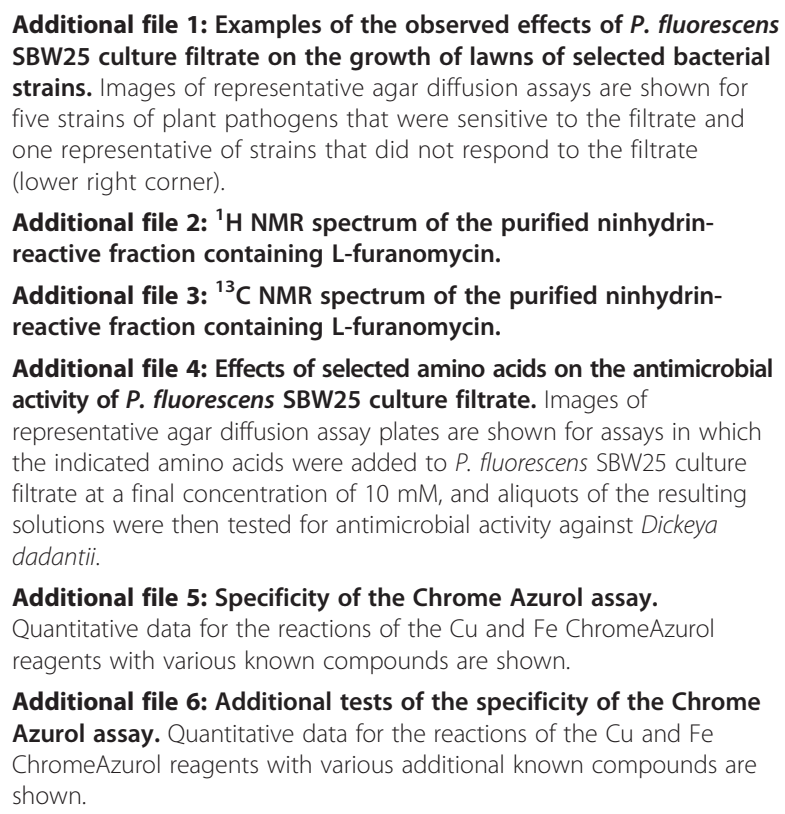

Additional file 2: ${ }^{1} \mathrm{H}$ NMR spectrum of the purified ninhydrinreactive fraction containing L-furanomycin.

Additional file $3:{ }^{13} \mathrm{C}$ NMR spectrum of the purified ninhydrinreactive fraction containing L-furanomycin.

Additional file 4: Effects of selected amino acids on the antimicrobial activity of $P$. fluorescens SBW25 culture filtrate. Images of

representative agar diffusion assay plates are shown for assays in which the indicated amino acids were added to P. fluorescens SBW25 culture filtrate at a final concentration of $10 \mathrm{mM}$, and aliquots of the resulting solutions were then tested for antimicrobial activity against Dickeya dadantii.

Additional file 5: Specificity of the Chrome Azurol assay.

Quantitative data for the reactions of the $\mathrm{Cu}$ and Fe ChromeAzurol reagents with various known compounds are shown.

Additional file 6: Additional tests of the specificity of the Chrome Azurol assay. Quantitative data for the reactions of the $\mathrm{Cu}$ and Fe ChromeAzurol reagents with various additional known compounds are shown.

\section{Author details}

'USDA-ARS National Forage Seed Production Research Center, Corvallis, OR 97331, USA. ${ }^{2}$ College of Pharmacy, Oregon State University, Corvallis, OR 97331, USA. ${ }^{3}$ Department of Botany and Plant Pathology, Oregon State University, Corvallis, OR 97331, USA.

Received: 8 November 2013 Accepted: 13 November 2013 Published: 19 November 2013

\footnotetext{
* Correspondence: Gary.Banowetz@ars.usda.gov

'USDA-ARS National Forage Seed Production Research Center, Corvallis, OR 97331, USA
}

\section{Biomed Central}

(c) 2013 Trippe et al.; licensee BioMed Central Ltd. This is an Open Access article distributed under the terms of the Creative Commons Attribution License (http://creativecommons.org/licenses/by/2.0), which permits unrestricted use, distribution, and reproduction in any medium, provided the original work is properly cited. The Creative Commons Public Domain Dedication waiver (http://creativecommons.org/publicdomain/zero/1.0/) applies to the data made available in this article, unless otherwise stated.

\section{Reference}

Trippe K, McPhail K, Armstrong D, Azevedo M, Banowetz G: Pseudomonas fluorescens SBW25 produces furanomycin, a non-proteinogenic amino acid with selective antimicrobial properties. BMC Microbiology 2013, $13: 111$.

\section{doi:10.1186/1471-2180-13-263}

Cite this article as: Trippe et al:: Correction: Pseudomonas sfluorescens SBW25 produces furanomycin, a non-proteinogenic amino acid with selective antimicrobial properties. BMC Microbiology 2013 13:263.
Submit your next manuscript to BioMed Central and take full advantage of:

- Convenient online submission

- Thorough peer review

- No space constraints or color figure charges

- Immediate publication on acceptance

- Inclusion in PubMed, CAS, Scopus and Google Scholar

- Research which is freely available for redistribution

Submit your manuscript at www.biomedcentral.com/submit
C Biomed Central 